\title{
Peran Kepolisian dalam Penyidikan Tindak Pidana Korupsi (Studi pada Kepolisian Daerah Sumatera Utara)
}

\section{The Role of the Police in Corruption Criminal Investigations (Study at the North Sumatra Regional Police)}

\author{
Herikson Parulian Siahaan1)*, Marlina2), Muaz Zul ${ }^{3)}$ \\ 1) Program Pasca Sarjana, Magister Ilmu Hukum, Universitas Medan Area, Indonesia \\ 2) Fakultas Hukum Universitas Sumatera Utara, Indonesia \\ 3) Fakultas Hukum Universitas Medan Area, Indonesia
}

\begin{abstract}
Abstrak
Tujuan penelitian ini adalah untuk mengetahui bagaimana pengaturan peran kepolisian dalam penyidikan tindak pidana korupsi, bagaimana kewenangan kepolisian dalam penyidikan tindak pidana korupsi dan bagaimana kendala yang dihadapi kepolisian dalam penyidikan tindak pidana korupsi di wilayah Polda Sumut. Penelitian ini diarahkan kepada penelitian hukum yuridis normatif, atau doktriner yang juga disebut sebagai penelitian perpustakaan atau studi dokumen, karena lebih banyak dilakukan terhadap data yang bersifat sekunder yang ada di perpustakaan. Penelitian hukum normatif atau doktriner yang diajukan dalam kajian ini adalah penelitian terhadap asas-asas hukum dengan mengadakan penelitian di Kepolisian Daerah Sumatera Utara. Hasil penelitian dan pembahasan menjelaskan pengaturan peran kepolisian dalam penyidikan tindak pidana korupsi ditemukan dalam Undang-Undang No 8 Tahun 1981 Tentang KUHAP, Undang-Undang No. 31 Tahun 1999 Tentang Tindak Pidana Korupsi sebagaimana telah diubah dengan Undang-Undang No. 20 Tahun 2001 serta Undang-Undang No. 2 Tahun 2002 Tentang Kepolisian Negara Republik Indonesia, dimana dari kesemua pengaturan tersebut menjelaskan bahwa penyidik termasuk dalam kasus tindak pidana korupsi adalah Pejabat Polisi Negara Republik Indonesia.

Kata Kunci: Kepolisian, Penyidikan, Korupsi.
\end{abstract}

\begin{abstract}
The purpose of this study was to determine how the role of the police in the investigation of corruption, how the authority of the police in investigating corruption and how the obstacles faced by the police in investigating corruption in the North Sumatra Regional Police. This research is directed towards normative juridical legal research or doctrinaire which is also referred to as library research or document study because more is done on secondary data in the library. Normative or doctrinaire legal research proposed in this study is a study of legal principles by conducting research in the North Sumatra Regional Police. The results of the research and discussion explaining the regulation of the role of the police in investigating criminal acts of corruption are found in Law No. 8 of 1981 concerning the Criminal Procedure Code, Law No. 31 of 1999 concerning Corruption Crimes as amended by Law No. 20 of 2001 and Law No. 2 of 2002 concerning the National Police of the Republic of Indonesia, in which of all the arrangements explained that the investigator included in the corruption case was the Republic of Indonesia's National Police Officer.
\end{abstract}

Keywords: Police, Investigations, Corruption.

How to Cite: Siahaan, H. P., Marlina., \& Zul, M. (2019). Peran Kepolisian dalam Penyidikan Tindak Pidana Korupsi (Studi pada Kepolisian Daerah Sumatera Utara). ARBITER: Jurnal Ilmiah Magister Hukum, 1(2), 137-147.

*E-mail: herikson @gmail.com

ISSN 2722-1865 (Online) 


\section{PENDAHULUAN}

Tuntutan terhadap paradigma good governance dalam era globalisasi ini meliputi seluruh kegiatan tidak dapat dielakkan lagi. Istilah good governance sendiri dapat diartikan terlaksananya tata ekonomi, politik, dan sosial yang baik. Jika kondisi good governance dapat dicapai maka terwujudnya negara yang bersih dan responsif (clean and responsive state), semaraknya masyarakat sipil (vibrant civil society) dan kehidupan bisnis yang bertanggung jawab (good corporate governance) bukan merupakan impian lagi. Lembaga-lembaga donor internasional seperti World Bank, IMF dan ADB juga menuntut ditegakkan paradigma good governance di negara-negara yang memperoleh bantuan dari mereka, termasuk Indonesia. Tuntutan ditegakkan good governance bagi Indonesia merupakan suatu keharusan yang harus diupayakan dan dicapai.

Salah satu hal yang harus dipenuhi untuk dapat mencapai good governance adalah adanya transparansi atau keterbukaan dan akuntabilitas dalam berbagai aktivitas baik aktivitas sosial, politik dan ekonomi serta penegakan hukum. Salah satu indikator adanya keterbukaan dan akuntabilitas tersebut adalah tingkat korupsi kolusi dan nepotisme (KKN) yang terjadi dalam aktivitas ekonomi pada berbagai tingkatan pelaku ekonomi. Tingkat keterbukaan dan akuntabilitas dari aktivitas ekonomi maka seharusnya semakin rendah pula kemungkinan KKN yang terjadi.

Fungsi dan peranan kepolisian dalam penyidikan tindak pidana korupsi di wilayah hukum Kepolisian Daerah Sumatera Utara (Polda Sumut) dan menempatkan kepolisian menjadi salah satu "pllars of integrity" dalam gerekan anti korupsi di Indonesia khususnya di Provinsi Sumatera Utara.

Kebijakan debirokratisasi dilakukan dengan cara mengurangi atau memangkas proses birokrasi. Contoh proses perijinan diperpendek dan atau dipermudah. Dengan kebijakan tersebut masyarakat atau investor diharapkan memperoleh kemudahan untuk memperoleh ijin untuk melakukan kegiatan ekonomi. Pemerintah juga mengembangkan sistem administrasi satu atap sehingga masyarakat memperoleh pelayanan yang lebih baik dari pihak birokrasi.

Kelemahan yang sangat mencolok dalam proses tercapainya good governance selama ini adalah tingginya korupsi yang terjadi. Korupsi dapat dikatakan merajalela terutama di kalangan birokrasi pada instansi publik atau lembaga pemerintah baik departemen maupun bukan departemen. Korupsi biasanya yang terjadi disertai dengan tindakan kolusi dan nepotisme. Kemudian di Indonesia dikenal dengan nama istilah korupsi, kolusi dan nepotisme (KKN).

Provinsi Sumatera Utara menurut versi Komisi Pemberantasan Korupsi (KPK) menempati urutan tiga setelah DKI Jakarta dan Jawa Timur soal dugaan korupsi, berdasarkan jumlah pengaduan masyarakat yang diterima KPK. Keseluruhan pengaduan yang diterima KPK dari masyarakat Sumut sebanyak 2,290 laporan terhitung sejak tahun 2009-2015.

Secara teoritis terjadinya korupsi dipengaruhi oleh faktor permintaan dan faktor penawaran. Dari sisi permintaan dimungkinkan karena adanya (1) regulasi dan otorisasi yang memungkinkan terjadinya korupsi, (2) karakteristik tertentu dari sistem perpajakan, dan (3) adanya provisi atas barang dan jasa di bawah harga pasar. Sedangkan dari sisi penawaran dimungkinkan terjadi karena (1) Tradisi birokrasi yang cenderung korup, (2) Rendahnya gaji di kalangan birokrasi, (3) Kontrol atas institusi yang tidak memadai, (4) Transparansi dari peraturan dan hukum.

Memberantas korupsi sehingga upaya terwujudnya good governance dapat lebih cepat tercapai maka perlu dukungan dan upaya dari berbagai pihak. Perlu diciptakan sistem akuntabilitas yang efektif. Pengambil kebijakan harus memfokuskan usaha 
mereka mencapai tujuan-tujuan sebagai berikut: 1) Para pemegang posisi kunci di lembaga eksekutif dan pelayanan masyarakat harus memperkuat institusi public; 2) Para politisi dan pegawai negeri harus secara kolektif bertanggung jawab atas pelaksanaan tugas dan komitmen pemerintah; 3) Para politis dan birokrat pada umumnya harus lebih responsif terhadap kebutuhan perusahaan-perusahaan milik swasta maupun milik negara; dan 4) Seluruh warga negara, sektor swwasta, media dan masyarakat sipil harus dididik dan diberdayakan untuk meningkatkan akuntabilitas sektor publik.

Peran Polri sebagai penyidik pada criminal justice system tindak pidana korupsi pada hakikatnya merupakan fungsionalisasi hukum pidana, artinya fungsionalisasi memegang peranan penting dalam suatu penegakan hukum, Barda Nawawi Arief menyatakan bahwa fungsionalisasi hukum pidana dapat berfungsi, beroperasi atau bekerja dan terwujud secara nyata. Fungsionalisasi hukum pidana identik dengan operasionalisasi atau konkretitasi hukum pidana, yang hakikatnya sama dengan penegakan hukum. Fungsionalisasi hukum pidana dapat diartikan sebagai upaya untuk membuat hukum pidana dapat berfungsi, beroperasi atau bekerja dan terwujud secara nyata. Fungsionalisasi hukum pidana identik dengan operasionalisasi atau konkretisasi hukum pidana, yang hakikatnya sama dengan penegakan hukum. Fungsionalisasi ini terdapat tiga tahapan kebijakan yaitu tahap kebijakan formulatif sebagai suatu tahap perumusan hukum pidana oleh pihak pembuat perundang-undangan. tahap kebijakan aplikatif sebagai tahap penerapan hukum pidana oleh penegak hukum, tahap kebijakan administratif, yaitu merupakan tahap pelaksanaan oleh aparat eksekusi hukum.

Suatu hal yang dipahami dari uraian di atas adalah sangat urgennya kedudukan penyidik Polri dalam mengungkapkan suatu tindak pidana termasuk salah satunya tindak pidana korupsi. Tetapi disebabkan tingkat sumber daya manusia polisi juga terbatas serta dibutuhkannya alat bukti dalam pengungkapan tindak pidana korupsi maka dalam kaitan ini Penyidik Polri juga membutuhkan lembaga lain yang memiliki kompetensi dalam melakukan tugas audit investigasi.

Kenyataan ini memberikan konstribusi bahwa kerjasama antara Kepolisian dengan lembaga lainnya amat sangat penting khususnya dalam menemukan kebenaran terhadap suatu hal yang diperkirakan berindikasi merugikan keuangan negara atau telah terjadi suatu peristiwa tindak pidana korupsi.

Penyidikan Tindak Pidana Korupsi yang mana terdapat beberapa lembaga yang berdasarkan peraturan perundang-undangan mempunyai tugas dan wewenang dalam penyidikan yakni Kepolisian Negara Republik Indonesia (POLRI) berdasarkan Pasal 14 ayat (1) huruf g Undang-Undang Nomor 2 Tahun 2002 tentang Kepolisian Negara Republik Indonesia, Kejaksaan berdasarkan ketentuan Pasal 30 ayat (1) huruf a Undang-Undang Nomor 16 Tahun 2004 Tentang Kejaksaan dan Komisi Pemberantasan Korupsi (KPK) berdasarkan ketentuan Pasal 6 huruf c Undang-Undang No. 30 Tahun 2002 tentang Komisi Pemberantasn Korupsi.

POLRI sebelum terbentuknya KPK diberikan kewenangan oleh pembuat undangundang untuk melakukan penyelidikan dan penyidikan terhadap semua tindak pidana, baik Tindak Pidana Umum maupun Tindak Pidana Korupsi. Pembentukan KPK yang khusus untuk memberantas korupsi mengingat lembaga pemerintahan yang menangani perkara Tindak Pidana Korupsi belum berfungsi secara efektif dan efisien, dalam melakukan pemberantasan terhadap Tindak Pidana Korupsi justru sering menimbulkan permasalahan dalam penanganan kasus korupsi, salah satu contoh adalah pada kasus Korupsi Pengadaan Simulator Surat Izim Mengemudi (SIM) pada Korlantas Mabes POLRI yang melibatkan POLRI dan KPK dimana keduanya mengklaim memiliki 
kewenangan untuk melakukan penyidikan.

\section{METODE PENELITIAN}

Bila dilihat dari sudut tujuan penelitian hukum, penelitian ini dikategorikan sebagai penelitian hukum bersifat yuridis empiris (penelitian hukum kepustakaan), yaitu dengan cara meneliti bahan pustaka atau data sekunder belaka, yang mencakup penelitian terhadap asas-asas hukum, sistematika hukum, sinkronisasi hukum, sejarah hukum, perbandingan hukum, serta hukum yang akan datang (futuristik). Di samping penelitian hukum normatif, penelitian ini juga berupaya untuk meneliti data primer, yang dikenal sebagai penelitian hukum yuridis empiris. Di dalam penelitian hukum normativ, maka penelitian terhadap azas-azas hukum dilakukan terhadap kaidahkaidah hukum, yang merupakan patokan-patokan berperilaku atau bersikap tidak pantas. Penelitian tersebut dapat dilakukan terutama bahan hukum primer dan sekunder yang mengandung kaidah-kaidah hukum. Penelitian terhadap sistematik hukum adalah khusus terhadap bahan-bahan hukum primer dan sekunder. Kerangka acuan yang dipergunakan adalah pengertian dasar dalam sistem hukum.

Adapun jenis data yang dibutuhkan dalam penelitian ini adalah data sekunder yaitu bahan-bahan pustaka. Dengan demikian, data ini bersumber dari kepustakaan, yaitu bahan hukum primer, bahan hukum sekunder dan bahan hukum tersier. Berdasarkan jenis dan sumber data tersebut, maka penelitian ini lazim disebut penelitian kepustakaan (library research). Sebagai penunjang bagi data sekunder tersebut, penelitian ini juga membutuhkan data primer, yakni data yang diperoleh secara langsung dari lapangan, masyarakat dan pemerintah. Data-data yang dimaksud adalah hasil survey dan wawancara yang dilakukan dengan Bapak Jadiaman Sinaga, selaku Penyidik Madya IV Tipikor Reskrimsus Polda Sumut.

\section{HASIL DAN PEMBAHASAN \\ Pengaturan Peran Kepolisian Dalam Penyidikan Tindak Pidana Korupsi}

Susunan dan kedudukan Kepolisian diberbagai negara di dunia selalu berkaitan dengan sistem pemerintahan dan sistem peradilan pidana yang dianut, bahkan sistem administrasi Kepolisian merupakan subsistem dari kedua sistem tersebut. Sistem pemerintahan negara atau sistem administrasi negara berkaitan dengan penyelenggaraan fungsi Kepolisian pada tataran Preventif dan Preemptif, sehingga mempunyai ciri-ciri fungsi utama administrasi negara yang meliputi: fungsi pengaturan, perijinan, pelaksaan sendiri tugas pokok, pengolahan, pengawasan dan fungsi penyelesaian perselisihan.

Sistem peradilan pidana berkait dengan penyelenggaraan fungsi Kepolisian pada tataran represif sehingga akan mempunyai ciri-ciri dari sistem peradilan pidana (Criminal justice system) antara lain mengenai asas yang dianutnya. Richard J. Terrill dalam bukunya "World criminal justice system" memperbandingkan criminal justice system diberbagai negara antara lain Inggeris, Perancis, Swedia, Jepang, dan Uni Soviet hanya berdasarkan komponen-komponen yang terdiri dari: The government, The police, The judiciary, The law, Corrections and juvenilie justice dan tidak mengkaitkannya dengan komponen Angkatan Perang atau Militer oleh karena secara universal memang diakui tidak menunjukan adanya kaitan. Selanjutnya dapat disimpulkan bahwa susunan dan kedudukan Kepolisian tidak ada dengan institusi Militer atau Angkatan Perang.

Pada dasarnya susunan dan kedudukan Polri ditiap negara menggambarkan konsepsi kepolisian yang dianut oleh negara yang bersangkutan dapat dikembalikan 
kepada dua aliran besar yaitu konsepsi Anglo Saxon dan konsepsi Eropa Kontinental. Dengan demikian menurut Undang-Undang Kepolisian No. 13 Tahun 1961 pengembanan kekuasan kepolisian secara hirarki terdiri dari Presiden, Menteri Kepolisian Negara, dan Kepala Kepolisian Negara serta disamping itu terdapat Kepala Daerah yang memegang pimpinan kebijakan politik polisionil dan koordinasi dinas vertikal di daerahnya. (R. Hamzah, 2019)

Bergulirnya era reformasi telah mengakibatkan perubahan besar dalam ketatanegaraan dan pemerintahan antara lain pengunduran diri Presiden Soeharto pada tanggal 21 Mei 1998 dan berdasarkan pasal 8 UUD 1945, Wakil Presiden BJ.Habibie menggantikan Presiden Soeharto sebagai Presiden Republik Indonesia. Dalam setiap proses Penyidikan, Penyidik selalu berpedoman pada Azas yaitu: 1) Azas Pemerataan di muka Umum/Persamaan Hak dalam hukum (Equality before the Law) adalah Penyidik memperlakukan setiap orang yang diduga terlibat dalam suatu tindak pidana tidak diskriminatif dimana semua mempunyai hak yang sama; dan 2) Azas Praduga Tak Bersalah (Presumption Of innocence) adalah semua orang yang ditangkap, diperiksa maupun ditahan tetap dianggap belum bersalah sebelum adanya kekuatan hukum tetap/ putusan pengadilan atas dirinya.

Tugas dan tanggung jawab Penyidik telah diatur jelas dalam UU RI No. 8 Tahun 1981 Tentang KUHAP dan UU RI No. 2 Tahun 2002 Tentang Kepolisian Negara Republik Indonesia. Pasal 4 sampai Pasal 9 KUHAP menguraikan tentang Penyidik adalah Pejabat kepolisian Negara Republik Indonesia yang mempunyai tugas dan tanggung jawab melakukan Penyelidikan, Penyidikan sampai penyerahan berkas perkara untuk semua tindak pidana yang terjadi termasuk tindak pidana korupsi dan tatacara dalam melaksanakan tugas dan tanggung jawab tersebut terurai dalam Pasal 102 sampai Pasal 136 KUHAP

Pada Undang-Undang No 2 Tahun 2002 Tentang Kepolisian Negara Republik Indonesia telah diuaraikan juga mengenai tugas dan tanggung jawab sebagai Penyidik, Pasal 14 huruf g menyatakan dalam tugas dan tanggung jawab penyidik berpedoman pada KUHAP. Salah satu tindak pdana yang sangat fenomenal adalah tindak pidana korupsi dimana setiap Negara maju, Negara berkembang, Negara miskin selalu dihadapkan dengan persoalan ini sehingga semakin majunya suatu Negara semakin tinggi pula angka kebocoran terhadap keuangan Negara.

Pemberantasan tindak pidana korupsi telah dilakukan pemerintah sejak dulu sejak dulu karena korupsi dianggap sebagai suatu penyakit masyarakat yang menggerogoti kesejahteraan masyarakat sehingga merugikan keuangan Negara dan perekonomian Negara. Telah banyak upaya yang telah dilakukan pemerintah dalam pemberantasan Tindak Pidana Korupsi ini dengan cara memberikan kewenangan kepada instansi terkait yang dianggap mampu dalam menangani hal ini (M.A, Siregar, dkk, Rizkan Zulyadi, dkk, Riswan Munthe, dkk 2019).

Pengaturan peran kepolisian dalam penyidikan tindak pidana korupsi ditemukan dalam berbagai peraturan perundang-undangan meliputi: 1) Undang-Undang No 8 Tahun 1981 Tentang KUHAP, dijelaskan bahwa Penyidik adalah Pejabat Polisi Negara Republik Indonesia, dan 2) Undang-Undang No. 31 Tahun 1999 Tentang Tindak Pidana Korupsi sebagaimana telah diubah dengan Undang-Undang No. 20 Tahun 2001 Tentang Perubahan atas Undang-Undang No. 31 Tahun 1999 Pasal 26 Berbunyi Penyidikan terhadap tindak pidana Korupsi dilakukan berdasarkan ketentuan dalam KUHAP.

Undang-undang ini memberikan kewenangan seluas-luasnya kepada Penyidik POLRI untuk melakukan penyidikan TP Korupsi yang dijelaskan dalam Undang-undang ini secara rinci dan memuat ketentuan pidana yaitu menentukan ancaman pidana 
minimum khusus, pidana denda yang lebih tinggi dan diancam pidana khusus yang merupakan pemberantasan tindak pidana korupsi.

Pasal 26 Undang-Undang No. 31 Tahun 1999 menjelaskan: Penyelidikan, Penuntutan dan pemeriksaan di sidang pengadilan terhadap tindak pidana Korupsi dilakukan berdasarkan hukum Acara Pidana yang berlaku dan ditentukan lain dalam undang-undang ini dimana kewenangan penyidik dalam pasal ini termasuk wewenang untuk melakukan penyadapan. Sesuai dengan ketentuan Pasal 5 dan Pasal 7 jouncto Pasal 108 KUHAP, Polri dalam menangani kasus perkara menerima aduan atau pun pelaporan. Pelaporan disampaikan atau ditujukan kepada: 1) Penyelidik, 2) Penyidik, dan 3) Penyidik Pembantu.

\section{Kewenangan Kepolisian Dalam Penyidikan Tindak Pidana Korupsi}

Kitab Undang-Undang Hukum Acara Pidana (KUHAP) di dalam Pasal 1 angka 4 menyatakan bahwa penyelidik itu adalah: "Pejabat Polisi Negara Republik Indonesia yang diberi wewenang oleh undang-undang ini untuk melakukan penyelidikan." Jadi yang dapat menjadi penyelidik adalah Pejabat Polisi Negara Negara Republik Indonesia, selain Pejabat Polisi Negara Republik Indonesia tidak bisa menjadi penyelidik (F.H. Lubis, Marlina, dkk, 2010). Tugas penyelidik ialah melakukan penyelidikan yang merupakan serangkaian tindakan penyelidik untuk mencari dan menemukan suatu peristiwa yang diduga sebagai tindak pidana guna menentukan dapat atau tidaknya dilakukan penyidikan menurut cara yang diatur dalam KUHAP (pasal 1 angka 5 KUHAP).

Contoh kasus dalam penelitian ini adalah saling mengklaim kewenangan penyidikan terhadap kasus Korupsi Pengadaan Simulator Surat Izim Mengemudi (SIM) pada Korlantas Mabes POLRI yang melibatkan POLRI dan KPK, kedua lembaga tersebut sama-sama beralasan memiliki dasar hukum dalam melakukan penyidikan dimana POLRI beralasan memiliki wewenang berdasarkan ketentuan dalam KUHAP dan Undang-Undang Nomor 2 Tahun 2002 tentang Kepolisian Negara Republik Indonesia, sedangkan KPK melakukan penyidikan berdasarkan ketentuan Pasal 6 huruf c UndangUndang No. 30 Tahun 2002 tentang Komisi Pemberantasn Korupsi. Kedua lembaga tersebut telah melakukan penyidikan dan masing-masing menetapkan tersangka antara lain: POLRI menetapkan lima tersangka yakni bekas Wakil Kepala Korps Lantas Brigadir Jenderal Didik Purnomo, Ketua Panitia Pengadaan Ajun Komisaris Besar Polisi Teddy Rusmawan, Bendahara Korps Lantas Komisaris Legimo, Direktur Utama PT Inovasi Teknologi Indonesia Sukotjo Bambang, dan Direktur Citra Mandiri Metalindo Abadi Budi Santoso. KPK telah menetapkan empat orang tersangka. Keempatnya adalah Didik, Sukotjo, Budi, dan Gubernur Akademi Kepolisian yang juga bekas Kepala Korps Lantas POLRI Inspektur Jenderal Djoko Susilo.

Jika mengacu ketentuan KUHAP terlihat bahwa penyidikan terhadap suatu tindak pidana dapat dilakukan oleh penyidik POLRI dan Penyidik Pegawai Negeri Sipil tertentu, pada prinsipnya POLRI mempunyai wewenang yang diamanatkan oleh undang-undang untuk melakukan penyidikan terhadap semua tindak pidana baik tindak pidana yang diatur didalam KUHP maupun tindak pidana khusus diluar KUHP termasuk didalamnya penyidikan terhadap Tindak Pidana Korupsi sebagai suatu Tindak Pidana Khusus. (Fadhlurrahman, dkk, Rafiqi, dkk, Kartika, Arie, dkk 2019).

Dengan diundangkannya Undang-Undang Nomor 30 Tahun 2002 Tentang Komisi Pemberantasan Korupsi, dibentuklah lembaga independen yang diberi nama Komisi Pemberantasan Korupsi (KPK), lembaga ini diberikan kewenangan oleh UndangUndang Nomor 30 Tahun 2002 untuk melakukan penyelidikan, penyidikan dan 
penuntan terhadap Tindak Pidana Korupsi, adapun tugas KPK terdapat dalam pasal 6 Undang-Undang Nomor 30 Tahun 2002 Tentang Komisi Pemberantasan Korupsi antara lain: Koordinasi dengan instansi yang berwenang melakukan pemberantasan Tindak Pidana Korupsi, supervisi terhadap instansi yang berwenang melakukan pemberantasan Tindak Pidana Korupsi, melakukan penyelidikan, penyidikan, dan penuntutan terhadap Tindak Pidana Korupsi, melakukan tindakan-tindakan pencegahan Tindak Pidana Korupsi, dan melakukan monitor terhadap penyelenggaraan pemerintahan negara.

Berdasarkan Pasal 43 Undang-Undang Nomor 31 Tahun 1999 Tentang Pemberantasan Tindak Pidana Korupsi sebagaimana telah dirubah dengan UndangUndang Nomor 20 Tahun 2001, Pemerintah Indonesia dalam rangka mewujudkan supremasi hukum dan meletakkan landasan kebijaksanaan usaha yang kuat dalam usaha memerangi Tindak Pidana Korupsi dengan membentuk badan khusus yang disebut Komisi Pemberantasan Korupsi (KPK), komisi ini dibentuk dengan pertimbangan bahwa lembaga pemerintah yang menangani masalah pidana korupsi belum berfungsi secara efektif dan efisien dalam pemberantasan pidana korupsi, sedangkkan pidana korupsi di Indonesia sudah meluas, perkembangannya terus meningkat dari tahun ketahun baik dari jumlah kasus yang terjadi maupun jumlah kerugian keuangan negara dan juga dari segi kualitas tindak pidana yang dilakukan semakin sistematis oleh karena itu Tindak Pidana Korupsi tidak lagi digolongkan sebagai tindak pidana biasa melainkan telah digolongkan dalam tindak pidana luar biasa.

Permasalahan mengenai korupsi hingga sekarang ini masih menjadi persoalan utama bangsa ini. Genderang perang menandakan semangat memerangi tindak pidana yang merugikan keuangan negara ini terus dikumandangkan. Namun ironisnya justru yang terjadi adalah lembaga pemerintah yang menangani perkara tindak pidana korupsi belum berfungsi secara efektif dan efisien dalam memberantas tindak pidana korupsi, pihak-pihak yang memegang kekuasaan yaitu aparat kepolisian dan kejaksaan bahkan hingga hakim yang seharusnya memberantas korupsi justru menjadi pihak terdepan yang terlibat dalam tindak pidana korupsi.

\section{Kendala yang Dihadapi Kepolisian dalam Penyidikan Tindak Pidana Korupsi di Wilayah Polda Sumut}

Karakteristik tindak pidana korupsi yang multi dimensi terkait dengan kompleksitas masalah lainnya, antara lain masalah sikap mental/moral, pola/sikap hidup dan budaya sosial, kebutuhan/tuntutan ekonomi dan struktur/sistem ekonomi, lingkungan hidup/sosial dan kesenjangan sosial ekonomi, struktur/budaya politik, peluang yang ada di dalam mekanisme pembangunan atau kelemahan birokrasi/prosedur administrasi (termasuk sistem pengawasan) di bidang keuangan dan pelayanan publik. Jadi kuasa dan kondisi yang bersifat kriminogen untuk timbulnya korupsi sangatlah luas (multidimensi) yaitu dapat dibidang moral, sosial, ekonomi, politik, budaya, kesenjangan sosial ekonomi, kelemahan birokrasi/administrasi dan sebagainya.

Disamping itu lemahnya sistem juga merupakan salah satu penyebab. Tidak dapat disangkal lemahnya mekanisme di berbagai sektor birokrasi dewasa ini, seperti dikeluhkan oleh pengusaha nasional termasuk pengusaha kecil maupun pengusaha asing, karena masih banyaknya mata rantai yang harus mereka lalui untuk memperoleh sesuatu ijin atau fasilitas kredit. Keadaan yang kurang menggembirakan ini menyebabkan suburnya suap menyuap dan pemberian komisi sebagai salah satu 
bentuk perbuatan korupsi namun kelemahan sistem tersebut tidak berdiri sendiri. Ia adalah produk dari intregitas moral, dan untuk memperbaiki sistem tersebut tergantung pada integritas moral, karena yang dapat berpikir perlunya diperbaiki sistem ialah orang yang bermoral.

Mengingat ciri-ciri tindak pidana korupsi yang multi terkait dengan kompleksitas masalah lainnya, antara lain masalah sikap mental/moral, masalah pola/sikap hidup dan budaya sosial, masalah kebutuhan/tuntutan ekonomi dan struktur/sistem ekonomi, masalah lingkungan hidup/sosial dan kesenjangan sosial ekonomi, masalah stuktur/budaya politik, masalah peluang yang ada di dalam mekanisme pembangunan dan kelemahan birokrasi/produser administrasi (termasuk sistem pengawasan) di bidang keuangan dan pelayanan publik. Faktor-faktor yang berasal dari masa silam dan masih melekat pada masyarakat yang bersangkutan seperti solidaritas kekeluargaan dan kebiasaan saling memberi hadiah di anggap sebagai sebab korupsi yang lain. Jadi kuasa dan kondisi yang bersifat kriminogen untuk timbulnya korupsi sangatlah luas (multidimensi), yaitu baik di bidang moral, sosial, ekonomi, politik, budaya, kesenjangan sosial ekonomi, kelemahan birokrasi/administrasi dan sebagainya.

Perkembangan pembangunan khususnya di sektor bidang ekonomi dan keuangan telah berjalan dengan cepat, serta banyak menimbulkan terjadinya perubahan dan berbagai peningkatan kesejahteraan yang mengakibatkan terjadinya perubahan tatanan nilai di masyarakat yang sementara orang digunakan untuk melakukan tindakantindakan penyimpangan dan manipulasi data dan korupsi. Kebijakan pemerintah dalam meningkatkan ekspor, peningkatan investasi melalui penanaman modal, kemudian di bidang perbankan merupakan sasaran tindak pidana korupsi.

Di samping itu pemusatan, wewenang dan tanggung jawab dalam penyelenggaraan negara serta partisipasi masyarakat yang lemah dalam menjalankan fungsi kontrol merupakan faktor penyebab meningkatnya korupsi di Indonesia. Faktor lain yang sering dianggap sebagai penyebab merebaknya korupsi adalah karena korupsi di anggap sudah membudaya dan menjadi bagian yang tidak dapat dipisahkan dari praktek kehidupan masyarakat sehari-hari.

\section{SIMPULAN}

Pengaturan peran kepolisian dalam penyidikan tindak pidana korupsi ditemukan dalam Undang-Undang No 8 Tahun 1981 Tentang KUHAP, Undang-Undang No. 31 Tahun 1999 Tentang Tindak Pidana Korupsi sebagaimana telah diubah dengan UndangUndang No. 20 Tahun 2001 Tentang Perubahan atas Undang-Undang No. 31 Tahun 1999 serta Undang-Undang No.2 Tahun 2002 Tentang Kepolisian Negara Republik Indonesia, dimana dari kesemua pengaturan tersebut menjelaskan bahwa Penyidik termasuk dalam kasus tindak pidana korupsi adalah Pejabat Polisi Negara Republik Indonesia.

Kewenangan kepolisian dalam penyidikan tindak pidana korupsi adalah wewenang penyidikan terhadap tindak pidana korupsi yang tidak melibatkan aparat penegak hukum, penyelenggara negara, dan orang lain yang ada kaitannya dengan Tindak Pidana Korupsi yang dilakukan oleh aparat penegak hukum atau penyelenggara negara, wewenang penyidikan terhadap tindak pidana korupsi yang tidak mendapat perhatian masyarakat dan atau wewenang penyidikan terhadap tindak pidana korupsi yang menyangkut kerugian negara kurang dari Rp.1.000.000.000,00 (satu milyar rupiah), dan POLRI juga berwenang melakukan penyidikan Tindak Pidana Korupsi dengan ketentuan KPK melimpahkan perkara korupsi tersebut kepada penyidik POLRI.

Kendala yang dihadapi kepolisian dalam penyidikan tindak pidana korupsi di 
wilayah Polda Sumut adalah sulitnya pembuktian sebagaimana dimaksud dalam Pasal 2 dan Pasal 3 UU No. 31 Tahun1999 tentang Pemberantasan tindak pidana korupsi, dan alat bukti yang dimaksud dalam Pasal 184 KUHAP. Demikian pula adanya peraturan perundang-undangan yang mengatur tentang ijin/persetujuan yang harus dimohonkan/diajukan baik oleh Polri maupun oleh Kejaksaan terlebih dahulu kepada Pejabat/Instansi tertentu dalam tindakan pemanggilan/pemeriksaan saksi/tersangka tertentu.

\section{DAFTAR PUSTAKA}

Achwan, Rochman, “Good Governance: Manifesto Politik Abad ke-21", Kompas, Rabu 28 Juni 2007.

Alastas, S. H. (1987). Korupsi Sifat, Sebab dan Fungsi. Jakarta: LP3ES.

Ardianto, Sigit, Hukum Responsif, Jurnal Hukum, Padjadjaran Review, Volume 01 No. 01 Tahun 2005.

Arens., \& Loebbecke. (2003). Auditing, Pendekatan Terpadu, Adaptasi oleh Amir Abadi Jusuf. Jakarta: Salemba Empat.

Arief, B. N. (1982). Masalah Pemidanaan Sehubungan Dengan Perkembangan Delik-Delik Khusus Dalam Masyarakat Modern. Bandung: Bina Cipta.

Arief, B. N. (1994). Teori-teori Kebijakan Pidana. Bandung: Alumni 1994.

Arief, B. N. (1998). Beberapa Aspek Kebijakan Penegakan dan Pengembangan Hukum Pidana, Bandung: PT. Citra Aditya Bakti.

Arief, Barda Nawawi, Kebijakan Kriminal, Semarang : Makalah disampaikan pada Seminar Krimonologi VI, Tanggal 16-18 September 1991.

Armada, W. (1989). Wajah Hukum Pidana Pers. Jakarta: Pustaka Kartini.

Atmasasmita, R. (1996). Sistem Peradilan Pidana (Criminal Justice System) Perspektif Eksistensialisme dan Abolisionisme. Jakarta: Putra A. Bardin.

Awaloedin, D, (2001). Menuju Polri Mandiri yang Profesional, Pengayom, Pelindung, Pelayan Masyarakat, Jakarta: Yayasana Tenaga Kerja Indonesia, 2001.

Bank, Asian Development (ADB), "Good Governance and Anticorruption: The Road Forwad for Indonesia", Paper, Presented at Eight Meeting of the Colsultative group on Indonesia, 27-28 July 1999, Paris, France.

Chazawi, Adami, Hukum Pembuktian Tindak Pidana Korupsi, Bandung : Alumni, 2006.

Departemen Informasi dan Komunikasi Republik Indonesia, Indeks Korupsi Indonesia berada di peringkat 143, http://www.depkominfo.go.id.

Dirdjosisworo, Soerjono, "Polisi Dalam Sistem Peradilan Pidana Indonesia", Majalah Bhayangkara N0. 05, Juli 1998.

Eddy Suhartono, "Perihal Ketentuan-Ketentuan Tindak Pidana Korupsi”, Buletin Pengawasan No. 28 \& 29 Th. 2001. http/www/google.com/korupsi.

Ediwarman, Monograf Metodologi Penelitian Hukum (Panduan Penelitian Tesis dan Disertasi), Medan: Program Pascasarjana Universitas Muhammadiyah Sumatera Utara, 2010.

Fadhlurrahman, Rafiqi \& Kartika, Arie. (2019). Proses Penyidikan Dalam Penyelesaian Tindak Pidana Kekerasan Dalam Rumah Tangga Yang Dilakukan Oleh TNI-AD (Studi Di Pengadilan Militer I-02 Medan). JUNCTO, 1(1) 2019: 52-64,

Hadjar, Abdul Fickar, Pengadilan Asongan : Realitas Sosial Dalam Perspektif hukum, Jakarta: Mitra Kerya, 2001.

Hamzah, Andi Hukum Acara Pidana Indonesia, Jakarta : CV Sapta Artha Jaya, 1996.

Hamzah, R. (2019). Implementasi Peran Serta Masyarakat dalam Pemberantasan Tindak Pidana Korupsi. Jurnal Ilmiah Penegakan Hukum, 6 (1) Juni 2019: 1-13.

Hamzah, R. (2019). Implementasi Peran Serta Masyarakat dalam Pemberantasan Tindak Pidana Korupsi. Jurnal Ilmiah Penegakan Hukum, 6 (1) Juni 2019: 1-13.

Harahap, A.R (2019). Upaya Penanggulangan terhadap Anggota Kepolisian yang Terlibat Tindak Pidana Peredaran Narkoba (Studi Kasus Di Kepolisian Resort Kota Besar Medan). Journal of Education, Humaniora and Social Sciences (JEHSS). 2 (2): 412-427.

Harahap, M.I.M. (2018). Analisis Yuridis Tindak Pidana Korupsi dengan Menggunakan Jabatan (Studi Putusan No. 296/Pid.B/2010/PN.Mdn). Journal of Education, Humaniora and Social Sciences (JEHSS). 1 (1): 1-8.

Hartanti, Evi, Penyelidikan, Penyidikan, Penuntutan dan pemeriksaan Di Sidang Kasus Koripsi, Bandung: CV. Mandar Maju, , 2008

Hartanti, Evi, Tindak Pidana Korupsi, Jakarta : Sinar Grafika, 2005. 
Hartono, C.F.G. Sunaryati, Penelitian Hukum di Indonesia pada akhir Abad ke-20, Alumni, Bandung, 1994. Hidayat, dan Ediwarman, (2013), Analisis Hukum Perlindungan Korban dalam Perkara Tindak Pidana Korupsi di Kabupaten Aceh Timur (Studi di Pengadilan Negeri IDI), Mercatoria, 6 (1): 44-63

HR., Ridwan, Hukum Administrasi Negara, Yogyakarta: UII Press, 2003.

Investigasi, Bidang -BPKP Perwakilan Propinsi Sumatera Utara, Peranan BPKP Dalam Pengungkapan Tindak Pidana Korupsi, Disampaikan pada Rapat kerja teknis Kasat reserse Kriminal Sejajaran Kepolisian Daerah Sumatera Utara, Medan, 04 Desember 2004.

Investigasi, Badan Pengawasan Keuangan dan Pembangunan Deputi Bidang, Petunjuk Pelaksanaan Pemeriksaan Khusus Kasus Penyimpangan Yang Berindikasi Merugikan Keuangan/Kekayaan Negara dan/Atau Perekonomian Negara, Jakarta, 2001.

Kanter, E. Y. dan Sianturi, S. R., Asas-asas Hukum Pidana di Indonesia dan Penerapnnya, Jakarta: Cetakan I (Alumni AHM-PTHM), 1982.

Kartanegara, Satoehid, Hukum Pembuktian Pencucian Uang, Bandung: MQS Publishing \& Ayyccs Group, 2006.

Khudzaifah, Dimyati, Dominasi Aliran Hukum: Studi Tentang Mains-Tream Positivism, dalam Jurnal Ilmu Hukum Universitas Muhammadiyah Surakarta, Vol. 7, No. 1 Maret 2004.

Komisi Hukum Nasional RI, Rekkomendasi Untuk Reformasi Hukum, Draft Pembentukan Pengadilan Tindak Pidana Korupsi.

Lubis, F.H., dan Marlina, (2010), Penegakan Hukum dalam Tindak Pidana Korupsi Pengadaan Barang dan Jasa (Studi pada Pengadilan Negeri Kuala Simpang), Mercatoria, 3 (2): 88-101

M. Abdul Kholiq, Eksistensi dalam Peradilan Korupsi di Indonesia, Jurnal Hukum No.26 Vol 11, Mei 2004.

Masyarakat Transparansi Indonesia, "Analisa Peraturan Perundang-undangan dan Lembaga Pemberantasan Korupsi”, http://www.transparansi.or.id/?id=150\&pilih=lihatpopulerberita.

Medy Yudistira, Optimalisasi Pemberantasan Korupsi, 2013 Harian Analisa.All rights reserved.

Muladi dan Mulder, Pembahasan Terhadap Buku Kesatu dan Bab II RUU KUHP, Jurnal Legislasi Indonesia, Vol Nomor 2, September 2004.

Muladi, Pembaharuan Hukum Pidana Yang Berkualitas Indonesia, Makalah Dalam Rangka HUT FH UNDIP, Semarang, tanggal 11 Januari 1988.

Nasution, Bismar Rezim Anti Money Laundering Untuk Memberantas Kejahatan Di Bidang Kehutanan, Disampaikan Pada Seminar, Pemberantasan Kejahatan Hutan Melalui Penerapan Undang-undang Tindak Pidana Pencucian Uang, yang diselenggarakan atas kerjasama Program Magister Ilmu Hukum Pascasarjana Universitas Sumatera Utara dengan Pusat Pelapor dan Analisis Transaksi Keuangan (PPATK), Medan, tanggal 6 Mei 2004

Nasution, Bismar, Pengkajian Ulang Hukum Sebagai Landasan Pembangunan Ekonomi, Pidato diucapkan pada Pengukuhan Jabatan Guru Besar Tetap dalam Ilmu Hukum Ekonomi Pada Fakultas Hukum Univesitas Sumatera Utara di Hadapan Rapat Terbuka Senat Universitas Sumatera Utara di Gelanggang Mahasiswa USU, Sabtu 17 April 2004

Paton, George Whitecross, A Text Book of Jurisprudence, Second Edition, Oxford: At the Clarendon Press, 1951.

Prinst, Darwan, Pemberantasan Tindak Pidana Korupsi, Bandung: PT. Citra Aditya Bakti, 2006.

Prodjohamidjojo, Martiman, Penerapan Pembuktian Terbalik Dalam Delik Korupsi, Bandung : Mandar Maju, 2001.

Rahmansyah, Abdi, Tinjaun Yuridis Tentang Kewenangan Penyidikan Dalam Tindak Pidana Korupsi, Jakarta: Bina Grafika, 2008.

Rasjidi, Lili, dan Rasjidi, Ira Thania, Pengantar Filsafat Hukum, Bandung: Mandar Maju, 2002.

Reksodiputro, Mardjono, Kejahatan Korporasi Suatu Fenomena Lama Dalam Bentuk Baru, Bahan Kuliah Hukum Pidana dan Kegiatan Perekonomian, Jakarta: Fakultas Hukum Pascasarjana Universitas Indonesia, 2005.

Reksodiputro, Mardjono, Kriminologi dan Sistem Peradilan Pidana, Jakarta : Pusat Pelayanan Keadilan dan Pengabdian Hukum, Lembaga Kriminologi, Universitas Indonesia, 1994.

Remmelink, Jan, Hukum Pidana, Jakarta: Gramedia Pustaka Utama, 2003.

Republik Indonesi, Keputusan Menteri Pendayagunaan Aparatur Negara No. 25 Tahun 2002 tentang Pedoman Pengembangan Budaya Kerja Aparatur Negara.

Republik Indonesia, Peraturan Pemerintah No. 71 Tahun 2000 tentang Tata Cara Pelaksanaan Peran Serta Masyarakat dan Pemberian Penghargaan Dalam Pencegahan dan Pemberantasan Tindak Pidana Korupsi.

Republik Indonesia, Undang-Undang No. 2 Tahun 2002 tentang Kepolisian Republik Indonesia

Republik Indonesia, Undang-Undang No. 20 Tahun 2001 tentang Perubahan Atas Undang-Undang No. 31 Tahun 1999 tentang Pemberantasan Tindak Pidana Korupsi 
Herikson Parulian Siahaan, Marlina, Muaz Zul, Peran Kepolisian dalam Penyidikan Tindak Pidana

Republik Indonesia, Undang-Undang No. 31 Tahun 1999 tentang Pemberantasan Tindak Pidana Korupsi Republik Indonesia, Keputusan Presiden No. 9 Tahun 2004 tentang Perubahan Keenam atas keputusan Presiden No. 103 Tahun 2001 tentang Kedudukan, Tugas, Fungsi, Kewenangan, Susunan organisasi dan Tata Kerja Lembaga Pemerintah Non Departemen.

Republik Indonesia, Peraturan Pemerintah No. 19 Tahun 2000 tentang Tim Gabungan pemberantasan Tindak Pidana Korupsi.

Republik Indonesia, Peraturan Pemerintah No. 20 Tahun 2001 tentang Pembinaan dan Pengawasan Atas Penyelenggaraan Pemerintahan Daerah, Instruksi Presiden No. 15 Tahun 1983 tentang Pedoman Pelaksanaan Pengawasan.

Republik Indonesia, Undang-Undang No. 17 Tahun 2003 tentang Keuangan Negara

Satiaman, Kewenangan Penyidik Dalam Penyidikan Tindak Pidana Korupsi, Diakses Melalui http://j4w4b4n.blogspot.co.id/2011/02/normal-0-false-false-false-en-us-x-none.html.

Siregar, M.A, Zulyadi, R \& Munthe, R. (2019). Pertanggungjawaban Pidana Terhadap Perbuatan Gratifikasi Dalam Tindak Pidana Korupsi (Studi Putusan No : 35/Pid.Sus.Tpk/2016/PN.Mdn). JUNCTO, 1(2) 2019: 113-120,

Soebroto, Brotodiretjo, Pengantar Hukum Kepolisian Umum Di Indonesia, Bandung, 1997.

Soekanto, Soerjono dan Marmudji, Sri Penulisan Hukum Normatif, Rajawali, Jakarta, 1986.

Soekanto, Soerjono, Sosiologi Suatu Pengantar, Jakarta, Rajawali Press 1999.

Sofa, "Bukti Audit dan Kertas Kerja Audit", http://massofa.wordpress.com.

Soyomukti, Nurani, Pengantar Sosiologi. Ar-Ruzz Media, Yogyakarta, 2010.

Subekti, Hukum Pembuktian, Jakarta: Pradya Paramita, 1987.

Sudarto, Hukum dan Perkembangan Masyarakat, Bandung: Sinar Baru, 1983.

Sunaryo, Sidik, Kapita Selekta Sistem Peradilan Pidana, Malang: UMM Pres, 2004.

Sunggono, Bambang. Metodologi Penelitian Hukum, cetakan ketiga Jakarta: Raja Grafindo Persada, 2001.

Suprapto, J. Metode Penelitian Hukum dan Statistik, Rineka Cipta, Jakarta, 2003.

Sutadi, Pola Membina Rasa Keadilan Masyarakat, Jakarta, Pusdiklat Kejaksaan Agung RI, 1991

Sutanto, "Peran POLRI Untuk Peningkatan Efektivitas Penerapan UU TPPU”, Kepala Kepolisian Negara Republik Indonesia, Keynote Address Pada Pelatihan Anti Tindak Pidana Pencucian Uang, Medan, tanggal 15 September 2005.

Tempo Online , Kasus Pengadaan Simulator Ujian SIM, Yusril Bela Polisi, Melalui http://www.tempo.co/read/news/2012/08/06/063421689/Kasus-Pengadaan-Simulator-UjianSIM-Yusril-Bela-Polisi.

Tempo.Com, Penyerahan Kasus Simulator tanpa SP3 Dinilai Benar, Diakses Melalui http://edsus.tempo.co/konten-berita/hukum/2012/10/23/437285/7/Penyerahan-KasusSimulator-Tanpa-SP3-Dinilai-Benar, diakses 4 Juni 2016.

Waspada, 12 Juni 2013, http://www.kpk.go.id/modules/news/article. php?storyid=2769.

Y. Sri Susilo, "Mampukah Ikatan Akuntan Indonesia (IAI) Menjadi Salah Satu Pillars If Integrity", http://www.transparansi.or.id/artikel/arikel pk/artikel 02.html.

Zebua, F.R.P., Iman J., dan Taufik S., (2008), Tanggungjawab Pelaku Tindak Pidana Korupsi dan Ahli Warisnya Dalam Pembayaran Uang Pengganti Kerugian Keuangan Negara Ditinjau Dari Aspek Hukum Perdata (Studi Kasus Pada Pengadilan Negeri Medan), Mercatoria, 1 (2): 150-162. 